\title{
Analisis Faktor-Faktor Yang Mempengaruhi Produksi Usahatani Bawang Merah di Kecamatan Tawangmangu
}

Vita Intari Afrianika $1^{*}$, Sri Marwanti ${ }^{2}$, Isti Khomah ${ }^{3}$

Progam Studi Agribisnis Fakultas Pertanian Universitas Sebelas Maret, Jl. Ir Sutami No.36A Surakarta, Indonesia 1 vitaafrianika30@gmail.com *; ${ }^{2}$ srimarwanti.uns@gmail.com ; ${ }^{3}$ stikhomah fp@yahoo.com

* corresponding author

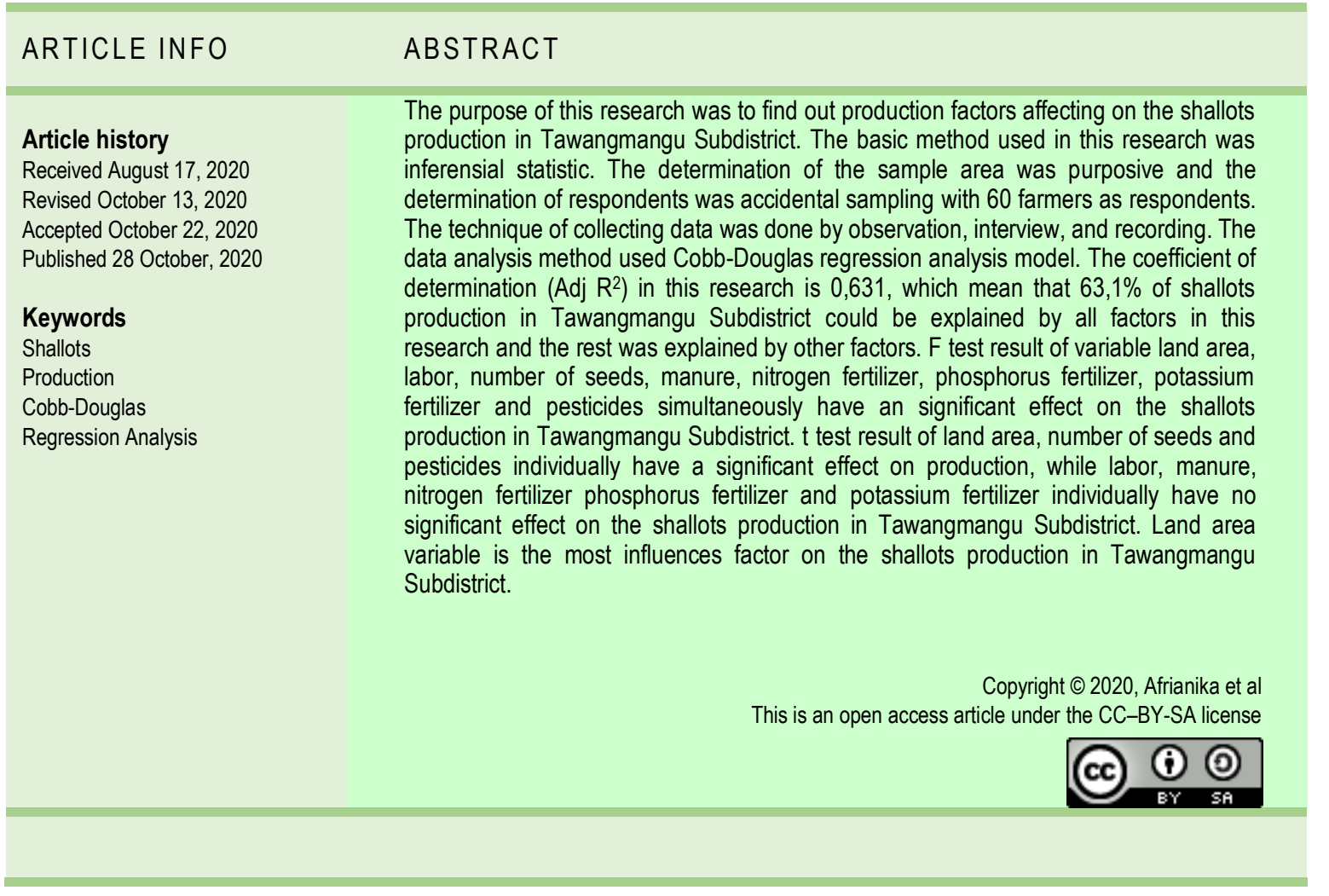

\section{PENDAHULUAN}

Pertanian merupakan salah satu sektor yang berperan penting dalam menunjang perekonomian Indonesia. Sektor pertanian selain sebagai sektor penyedia pangan juga merupakan sektor penyedia lapangan kerja bagi sebagian besar penduduk Indonesia. Menurut Sadono (2008), peranan lain dari sektor pertanian yaitu sebagai penyedia bahan mentah bagi sektor industri serta menghasilkan devisa negara. Sektor pertanian terdiri dari berbagai subsektor, salah satunya hortikultura. Hortikultura merupakan kegiatan bercocok tanam seperti sayursayuran, buah-buahan, maupun tanaman hias. Wilayah Indonesia memiliki keragaman agroklimatologi yang memungkinkan pengembangan berbagai jenis tanaman hortikultura baik tanaman dataran tinggi maupun dataran rendah. 
Menurut Mulyadi (2017) permasalahan dan hambatan dalam pengembangan hortikultura adalah kepemilikan modal yang terbatas, luas lahan sempit, kesesuaian agroklimat dengan tanaman, mutu benih unggul tidak cukup tersedia, serangan Organisme Pengganggu Tanaman (OPT), pengendalian hama yang belum baik. Hal ini disebabkan oleh berbagai faktor yaitu pola usahatani yang kecil, mutu bibit yang rendah, dan rendahnya penerapan teknologi budidaya. Peluang pasar dalam negeri bagi komoditas hortikultura diharapkan akan semakin meningkat dengan semakin meningkatnya jumlah penduduk dan pendapatan masyarakat.

Bawang merah merupakan salah satu jenis tanaman hortikultura yang banyak dibudidayakan di Indonesia. Bawang merah dapat tumbuh di dataran rendah maupun dataran tinggi. Berbagai varietas bawang merah dibudidayakan di Indonesia tergantung dengan kondisi daerahnya. Bawang merah menjadi salah satu komoditas sayuran yang setiap harinya dikonsumsi oleh masyarakat Indonesia, sehingga kebutuhan bawang merah akan semakin meningkat seiring dengan pertambahan jumlah penduduk. Konsumsi yang tinggi tersebut perlu diimbangi dengan produksi yang tinggi pula untuk memenuhinya.

Bawang merah menjadi komoditas sayuran dengan produksi tertinggi nomor dua di Indonesia dengan total produksi pada tahun 2018 sebesar 1.503 .438 ton. Jawa Tengah sebagai provinsi tertinggi penghasil bawang merah dibandingkan dengan provinsi lainnya dengan produksi sebesar 445.585 ton. Kabupaten karanganyar sebagai salah satu daerah penghasil bawang merah di provinsi jawa tengah dengan produksi sebesar 20.541 kwintal pada tahun 2018. Terdapat sepuluh kecamatan yang memproduksi bawang merah di Kabupaten Karanganyar, salah satunya Kecamatan Tawangmangu dengan produksi sebesar 11.150 kwintal.

Tawangmangu menjadi kecamatan yang tertinggi dalam produksi bawang merah. Tawangmangu merupakan daerah dengan ketinggian rata-rata 1000 mdpl, sehingga cocok ditanami sayuran maupun buahbuahan. Bawang merah merupakan tanaman sayuran yang dapat tumbuh didataran rendah sampai dataran tinggi tergantung dari jenis varietasnya. Bawang merah yang ditanam didaerah Tawangmangu adalah varietas bali lancur dan bali karet.

Kecamatan Tawangmangu sebagai penghasil bawang merah terbesar dibandingkan dengan kecamatan yang lain di Kabupaten Karanganyar. Produksinya pada tahun 2015 hingga 2018 mengalami fluktuatif, sedangkan bawang merah yang menjadi kebutuhan setiap hari mengalami peningkatan konsumsi dengan seiring bertambahnya jumlah penduduk setiap tahunnya. Bawang merah di Kecamatan Tawangmangu dengan produktivitas 98,47 kw/ha masih berada dibawah Kecamatan Ngargoyoso yaitu sebesar 112,60 kw/ha. Meskipun demikian Kecamatan Tawangmangu mengalami peningkatan areal luas panen, sehingga menjadi kecamatan dengan luas areal panen terbesar dibandingkan kecamatan lainnya. Namun peningkatan areal luas panen tidak serta merta meningkatkan produktivitas bawang merah yang dihasilkan. Sejalan dengan penelitian Widyantara dan Nengah (2013) bahwa luas lahan tidak mempengaruhi produksi bawang merah.

Besarnya produksi bawang merah erat kaitannya dengan penggunaan faktor-faktor produksi didalamnya. Menurut Susanti et al (2018) perbedaan penggunaan faktor-faktor produksi akan mengakibatkan perbedaan produksi yang dihasilkan. Kombinasi penggunaan faktor-faktor produksi sangat menentukan jumlah produksi bawang merah yang dihasilkan agar kegiatan usahatani senantiasa dapat memberikan keuntungan yang optimal. Penelitian terdahulu Susanti meneliti pengaruh faktor produksi terhadap produksi bawang merah. Faktor produksi yang diteliti diantaranya luas lahan, tenaga kerja, jumlah bibit, jumlah pupuk organik, jumlah pupuk NPK, dan jumlah pestisida. Penelitian Susanti menganalisis pengaruh faktor produkti tersebut terhadap produksi bawang merah dengan menggunakan analisis regresi linier berganda. Berdasarkan penelitian tersebut maka pembaharuan pada penelitian ini yaitu menganalisis pengaruh faktor produksi terhadap produksi bawang merah di Kecamatan Tawangmangu. Faktor produksi yang diteliti diantaranya luas lahan, tenaga kerja, jumlah bibit, pupuk kandang, pupuk nitrogen, pupuk fosfor, pupuk kalium, dan pestisida. Selain itu analisis dalam penelitian ini dengan menggunakan analisis regresi linier berganda fungsi produksi Cobbdouglass. Oleh karena itu, penelitian ini bertujuan untuk menganalisis pengaruh faktor-faktor produksi (luas lahan, tenaga kerja, jumlah bibit, pupuk kandang, pupuk nitrogen, pupuk fosfor, pupuk kalium, pestisida) terhadap produksi bawang merah di Kecamatan Tawangmangu.

\section{METODE PENELITIAN}

Penelitian ini menggunakan metode dasar statistik inferensia. Lokasi penelitian ditentukan secara purposive (sengaja) di dua desa di Kecamatan Tawangmangu, Kabupaten Karanganyar yaitu Desa Kalisoro dan Desa Blumbang dengan pertimbangan bahwa kedua desa dengan produksi bawang merah yang cukup tinggi dibandingkan desa lainnya. Penelitian ini menggunakan 60 sampel petani. Penentuan jumlah sampel pada

80

Afrianika et.al (Analisis Faktor-Faktor yang Mempengaruhi Produksi Usahatani Bawang Merah di Kecamatan Tawangmangu,Shallot, Production, Cobb-Douglas, Regression Analysis) 
setiap desa secara proporsional dengan metode pengambilan sampel secara accidental sampling. Data yang digunakan adalah data primer dan data sekunder. Data primer diperoleh dari wawancara langsung dengan petani responden. Data Sekunder diperoleh dari instansi pemerintah atau lembaga terkait, yaitu Badan Pusat Statistik, Dinas Pertanian dan Tanaman Pangan serta dari instansi lain yang relevan dengan penelitian ini. Pengumpulan data dilakukan secara observasi, wawancara, dan pencatatan.

\section{Metode Analisis Data}

Untuk menilai dan mengetahui pengaruh faktor produksi terhadap produksi usahatani bawang merah, di estimasi dengan regresi linier berganda. Model dari fungsi Cobb-Douglas sebagai berikut:

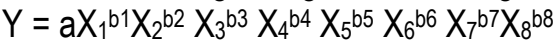

Selanjutnya persamaan tersebut kemudian diubah dalam bentuk linier berganda dengan cara melogaritmakan persamaan tersebut Soekartawi (2003). Adapun bentuk linier berganda rumus diatas setelah dilogaritmakan adalah:

$\log Y=\log a+b_{1} \log X_{1}+b_{2} \log X_{2}+b_{3} \log X_{3}+b_{4} \log X_{4}+b_{5} \log X_{5}+b_{6} \log X_{6}+b_{7} \log X_{7}+b_{8} \log X_{8}$ keterangan:

$\log Y=$ Produksi bawang merah $(\mathrm{kg})$

$\log X_{1}=$ Luas Lahan (Ha/MT)

$\log X_{2}=$ Jumlah Bibit (Kg/MT)

Log $X_{3}=$ Tenaga Kerja (HKO/MT)

$\log X_{4}=$ Pupuk Kandang (Kg/MT)

$\log X_{5}=$ Pupuk Nitrogen (Kg/MT)

$\log X_{6}=$ Pupuk Fosfor (Kg/MT)

$\log X_{7}=$ Pupuk Kalium (Kg/MT)

$\log X_{8}=$ Pestisida (ml/MT)

bi $\quad=$ koefisien regresi $(i=1,2, \ldots 9)$

a $\quad=$ konstanta

Uji Asumsi Klasik yang dilakukan uji normalitas, uji multikolinearitas dan uji heteroskedastisitas untuk mengetahui persamaan yang diperoleh bersifat BLUE (Best Linier Unbiased Estimated). Uji koefisien determinasi $\left(\mathrm{Adj}^{2}\right)$ digunakan untuk mengetahui proporsi sumbangan faktor produksi terhadap hasil produksi bawang merah, dengan rumus:

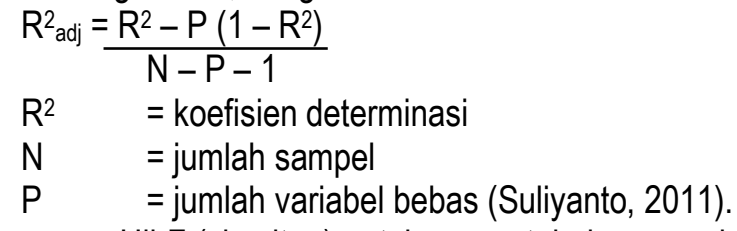

Uji F (simultan) untuk mengetahui pengaruh dari faktor produksi secara bersama-sama terhadap hasil produksi bawang merah, dengan rumus:

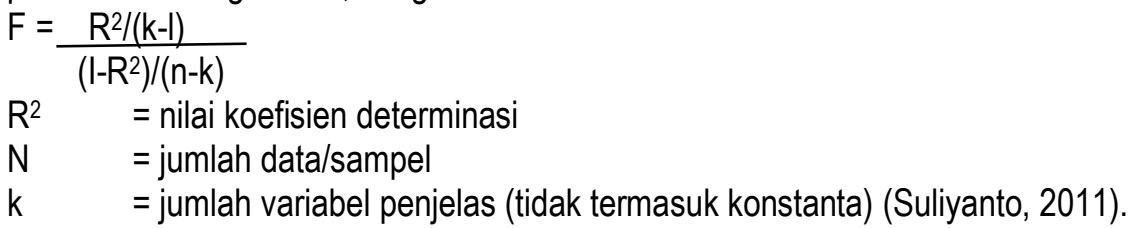

Pengaruh dari masing-masing faktor produksi terhadap hasil produksi bawang merah digunakan uji keberartian koefisien regresi dengan uji t, dengan rumus:

$t_{\text {hitung }}=\frac{b j}{s b j}$

bj = koefisien regresi ke- $\mathrm{i}$

Sbj = standar error koefisien regresi ke-I (Suliyanto, 2011).

Dengan hipotesis :

Ho : $b i=0$

$\mathrm{Hi}: \mathrm{bi} \neq 0$

Pada tingkat signifikansi $\alpha=5 \%$

a) Jika $t$ hitung $>t$ tabel maka Ho ditolak Hi diterima, yang berarti faktor produksi ke-i berpengaruh nyata terhadap hasil produksi bawang merah.

Afrianika et.al (Analisis Faktor-Faktor yang Mempengaruhi Produksi Usahatani Bawang Merah di Kecamatan Tawangmangu,Shallot, Production, Cobb-Douglas, Regression Analysis) 
b) Jika $t$ hitung $\leq \mathrm{t}$ tabel maka Ho diterima Hi ditolak, yang berarti faktor produksi ke-i tidak berpengaruh nyata terhadap hasil produksi bawang merah.

Mengetahui faktor produksi yang paling berpengaruh terhadap hasil produksi bawang merah digunakan standar koefisien regresi parsial (Koefisien Beta). Nilai koefisien regresi parsial yang paling besar merupakan faktor produksi yang paling berpengaruh terhadap hasil produksi bawang merah di Kecamatan Tawangmangu (Gujarati, 2007).

\section{HASIL DAN PEMBAHASAN}

\section{Usahatani Bawang Merah di Kecamatan Tawangmangu}

Proses budidaya meliputi persiapan bibit, pengolahan tanah, penanaman, pemupukan, penyiangan, pengendalian OPT, pengairan, panen dan pasca panen. Petani pada umumnya melakukan pembibitan sendiri. Bawang merah yang akan digunakan sebagai bibit dibersihkan dari sisa daun dan tanah, dijemur hingga kering dan kemudian disimpan. Rata-rata petani yang memiliki luas lahan 400-500 $\mathrm{m}^{2}$ membutuhkan bibit sebanyak $1 \mathrm{kwintal}$ atau $100 \mathrm{~kg}$. Tahap pengolahan tanah biasanya sekaligus pemberian pupuk dasar yaitu pupuk kandang maupun organik. Beberapa petani menggunakan pupuk kimia seperti phonska dan TSP. Setelah tercampur dan tanah sudah diratakan proses selanjutnya pembuatan guludan. Ukuran guludan disesuaikan dengan keadaan tanah, biasanya dengan lebar $\pm 80-100 \mathrm{~cm}$, tinggi $\pm 30-40 \mathrm{~cm}$, dan panjang menyesuaikan ukuran petakan lahan. Jarak antar guludan $\pm 20-25 \mathrm{~cm}$. Penanaman dilakukan secara langsung dengan memasukkan bibit bawang merah kedalam tanah dengan ujung berada di atas. Tanah dilubangi kecil-kecil dengan menggunakan tugal. Kedalaman penanaman berkisar sama dengan tinggi umbi bibit, arak tanam bawang merah antara $10-15 \mathrm{~cm}$.

Pemupukan susulan dilakukan 1-3 kali, tergantung dari masing-masing petani. Pupuk yang digunakan antara lain TSP, phonska, urea dan NPK. Cara pemupukan yaitu dengan menaburkan diantara barisan tanaman. Penyiangan dilakukan dengan mencabuti rumput atau gulma. Penyiangan dilakukan 1-4 kali selama masa tanam tergantung dari banyaknya gulma yang tumbuh pada tanaman. Hama yang biasanya menyerang tanaman bawang merah adalah ulat grayak. Sementara penyakit yang biasanya menyerang yaitu busuk daun atau hawar daun, layu fusarium, terlebih pada saat musim penghujan. Pengendalian hama dan penyakit yang menyerang tanaman bawang merah tersebut dilakukan dengan penyemprotan insektisida maupun fungisida. Penyemprotan tersebut dilakukan kurang lebih 3-7 hari sekali. Proses pengairan pada saat musim penghujan tidak ada, atau hanya memanfaatkan air hujan. Pengairan pada musim kemarau dilakukan dengan sistem leb, yaitu dengan menggenangi guludan dengan air yang dilakukan seminggu 1-2 kali. Tanaman bawang merah yang siap dipanen biasanya pada umur diatas 90-100 hari setelah tanam (HST) atau menyesuaikan daya tahan tanaman pada musim kemarau, sedangkan pada musim penghujan 60-70 hari setelah tanam. Setelah bawang merah dipanen, selanjutnya yaitu pengeringan. Sebelum pengeringan terlebih dahulu bawang merah dibersihkan dari sisa tanah dan daun yang masih menempel. Apabila cuaca cerah dengan panas matahari cukup, 3-4 hari bawang merah sudah cukup kering.

\section{Karakteristik Petani Bawang Merah di Kecamatan Tawangmangu}

Karakteristik petani bawang merah di Kecamatan Tawangmangu sebagian besar petani dalam usia produktif yaitu dalam rentang usia 15-64 tahun sejumlah 50 petani. Tingkat usia akan berpengaruh terhadap pengetahuan dan penyerapan informasi serta teknologi masing-masing petani. Perbedaan usia dapat mempengaruhi pengambilan keputusan petani dalam menjalankan usahatani bawang merah. Pendidikan dari sebagian besar petani adalah tamat SD sebanyak 38 orang atau 63,33 persen yang berarti tergolong masih rendah. Tingkat pendidikan yang rendah akan mempengaruhi petani dalam menjalankan usahataninya.

Rata-rata pengalaman berusahatani 31,9 tahun dan rata-rata luas garapan 0,053 ha. Meskipun petani memiliki tingkat pendidikan yang rendah, namun memiliki pengalaman usahatani yang cukup lama. Pengalaman inilah yang dijadikan pedoman petani untuk berusahatani bawang merah lebih baik sehingga dapat meningkatkan produksi. Menurut Sjamsir (2017) bahwa karakteristik sosial ekonomi mempengaruhi proses produksi pertanian, terutama berkaitan dengan proses pengambilan keputusan dalam pengelolaan usahatani diantaranya pendidikan petani, pengalaman petani dan lain-lain. Sebagian besar petani dengan status pemilik penggarap dengan 48 petani atau 80 persen dari jumlah petani. Umumnya petani pemilik penggarap lebih hemat dalam pengeluaran biaya produksi dibanding petani penyewa yang harus mengeluarkan tambahan biaya untuk menyewa lahan.

\section{2}

Afrianika et.al (Analisis Faktor-Faktor yang Mempengaruhi Produksi Usahatani Bawang Merah di Kecamatan Tawangmangu,Shallot, Production, Cobb-Douglas, Regression Analysis) 


\section{Analisis Faktor-Faktor yang Mempengaruhi Produksi Bawang Merah}

Pengaruh faktor-faktor produksi terhadap hasil produksi bawang merah di Kecamatan Tawangmangu dapat diketahui dengan menggunakan model fungsi produksi Cobb-Douglas. Hasil dari analisis data yang dilakukan dengan software SPSS menghasilkan model sebagai berikut:

$\log Y=\log 2,508+0,706 \log X_{1}-0,229 \log X_{2}+0,443 \log X_{3}-0,055 \log X_{4}+0,039 \log X_{5}+0,088 \log X_{6}-$ $0,139 \log X_{7}+0,194 \log X_{8}$

Persamaan yang telah di antilog kan:

$\mathrm{Y}=2,508 \mathrm{X}_{1}{ }^{0,706} \mathrm{X}_{2^{-0,229}} \mathrm{X}_{3}{ }^{0,443} \mathrm{X}_{4}^{-0,055} \mathrm{X}_{5}{ }^{0,039} \mathrm{X}_{6}{ }^{0,088} \mathrm{X}_{7^{-0,139}} \mathrm{X}_{8}{ }^{0,194}$

\section{Uji Asumsi Klasik}

Penelitian ini menggunakan beberapa uji untuk mengetahui ada tidaknya penyimpangan terhadap asumsi klasik diantaranya uji normalitas, uji multikolinearitas, dan uji heteroskedastisitas. Hasil signifikansi dari uji normalitas dengan uji Kolmogorov-Smirnov diperoleh nilai asymp. Sig (2-tailed) sebesar 0,960 > 0,05 yang berarti bahwa data pada penelitian ini berdistribusi normal. Hasil uji multikolinearitas dari kesemua variabel menunjukkan nilai Tolerance lebih besar dari 0,1 (Tolerance> 0,1) dan nilai VIF masing-masing variabel menunjukkan lebih kecil dari 10 (VIF < 10) yang artinya dalam model regresi tersebut tidak terjadi multikolinearitas. Hasil dari pengujian heteroskedastisitas menggunakan diagram scatter plot bahwa titik-titik menyebar secara acak dan tidak membentuk pola tertentu atau teratur. Hal tersebut menunjukkan bahwa kesalahan pengganggu memiliki varian yang sama (homoskedastisitas) dan dapat disimpulkan bahwa model regresi yang diestimasi tidak terjadi heteroskedastisitas.

Uji Statistik

Tabel 3. Hasil Analisis Regresi Faktor-Faktor yang Mempengaruhi Produksi Bawang Merah di Kecamatan Tawangmangu

\begin{tabular}{|c|c|c|c|c|c|}
\hline \multirow[t]{2}{*}{ Variabel } & \multicolumn{2}{|c|}{$\begin{array}{l}\text { Unstandardized } \\
\text { Coefficients }\end{array}$} & \multirow{2}{*}{$\begin{array}{c}\begin{array}{c}\text { Standardized } \\
\text { Coefficients }\end{array} \\
\text { Beta }\end{array}$} & \multirow[t]{2}{*}{$T$} & \multirow[t]{2}{*}{ Sig. } \\
\hline & B & Std. Error & & & \\
\hline Konstan & 2,508 & 0,768 & & 3,266 & $0,002^{* * *}$ \\
\hline Luas Lahan & 0,706 & 0,216 & 0,505 & 3,265 & $0,002^{* * *}$ \\
\hline Tenaga Kerja & $-0,229$ & 0,240 & $-0,151$ & $-0,955$ & $0,344^{\mathrm{ns}}$ \\
\hline Jumlah Bibit & 0,443 & 0,158 & 0,387 & 2,811 & $0,007^{* * * *}$ \\
\hline Pupuk Kandang & $-0,055$ & 0,200 & $-0,042$ & $-0,274$ & $0,785^{\mathrm{ns}}$ \\
\hline Pupuk Nitrogen & 0,039 & 0,110 & 0,044 & 0,350 & $0,728^{\text {ns }}$ \\
\hline Pupuk Fosfor & 0,088 & 0,088 & 0,122 & 1,001 & $0,322^{\mathrm{ns}}$ \\
\hline Pupuk Kalium & $-0,139$ & 0,147 & $-0,141$ & $-0,943$ & $0,350^{\text {ns }}$ \\
\hline Pestisida & 0,194 & 0,084 & 0,233 & 2,296 & $0,026^{* *}$ \\
\hline R Square & & 0,682 & & & \\
\hline Adjusted R Square & & 0,631 & & & \\
\hline F hitung & & 13,393 & & & $0,000^{* * *}$ \\
\hline F tabel & & 2,13 & & & \\
\hline t tabel $1 \%$ & & 2,67373 & & & \\
\hline t tabel $5 \%$ & & 2,00665 & & & \\
\hline
\end{tabular}

Sumber : Analisis Data Primer, 2020

Keterangan:

*** = berpengaruh nyata pada tingkat kepercayaan $99 \%$

** = berpengaruh nyata pada tingkat kepercayaan $95 \%$

ns $\quad=$ tidak berpengaruh nyata

Nilai Adjusted R Square sebesar 0,631. Nilai Adj $R^{2}$ tersebut mengartikan bahwa sebesar $63,1 \%$ produksi bawang merah di Kecamatan Tawangmangu dapat dijelaskan oleh variabel bebas yang dijelaskan dalam model, seperti luas lahan (X1), tenaga kerja (X2), jumlah bibit (X3), pupuk kandang (X4), pupuk nitrogen (X5), pupuk fosfor (X6), pupuk kalium (X7) dan pestisida (X8). Sedangkan, sisanya sebesar 36,9\% dijelaskan oleh 
variabel lain diluar penelitian, seperti cuaca, iklim, pengalaman berusahatani, umur petani, teknologi dan lainlain.

Hasil uji Fmenunjukkan hasil pengujian serentak seluruh parameter dugaan pada tingkat kepercayaan $95 \%$ menunjukkan bahwa nilai $\mathrm{F}$ tabel > Fhitung $(13,393>2,13)$. Hal ini dapat dikatakan bahwa variabel bebas yang meliputi luas lahan, tenaga kerja, jumlah bibit, pupuk kandang, pupuk nitrogen, pupuk fosfor, pupuk kalium, dan pestisida secara bersama-sama berpengaruh nyata terhadap produksi bawang merah di Kecamatan Tawangmangu. Hasil uji t menunjukkan variabel luas lahan, jumlah bibit dan pestisida secara individu berpengaruh nyata terhadap produksi bawang merah di Kecamatan Tawangmangu. Sedangkan variabel tenaga kerja, pupuk kandang, pupuk nitrogen, pupuk posfat dan pupuk kalium tidak berpengaruh nyata terhadap produksi bawang merah di Kecamatan Tawangmangu.

Luas lahan memiliki nilai thitung $>t$ tabel yaitu 3,265> 2,67373 yang berarti luas lahan berpengaruh nyata terhadap produksi bawang merah di Kecamatan Tawangmangu pada tingkat kepercayaan $99 \%$. Besaran koefisien regresi dalam fungsi produksi Cobb-Douglas menunjukkan besaran elastisitas dari faktor produksi terhadap hasil produksinya (Soekartawi, 2003). Koefisien regresi luas lahan sebesar 0,706 yang berarti luas lahan mempunyai nilai elastisitas 0,706 artinya apabila ada penambahan luas lahan sebesar $1 \%$ maka terjadi peningkatan jumlah produksi bawang merah sebesar 0,706 \% dengan asumsi bahwa variabel lainnya dianggap nol atau konstan. Hasil tersebut sejalan dengan penelitian Awami et al (2018) yang menyatakan bahwa luas lahan sebagai salah satu faktor yang mempengaruhi produksi bawang merah. Semakin besar luas lahan semakin tinggi produksi bawang merah yang dihasilkan. Pertambahan luas lahan berarti terjadi pertambahan populasi tanaman, dengan demikian produksi bertambah seiring dengan bertambahnya jumlah tanaman.

Tenaga kerja memiliki nilai $t$ hitung $<t$ tabel yaitu $-0,955<2,00665$ yang berarti tenaga kerja tidak berpengaruh nyata terhadap produksi bawang merah di Kecamatan Tawangmangu. Hasil tersebut sejalan dengan penelitian Langi et al (2019) yang menyatakan bahwa tenaga kerja tidak mempengaruhi produksi bawang merah. Tenaga kerja yang terlalu banyak tidak akan berpengaruh pada penambahan produksi bawang merah. Hal ini akan mengakibatkan berlebihnya tenaga yang dicurahkan dan penggunaan tenaga kerja menjadi tidak efisien.

Jumlah bibit memiliki nilai t hitung $>$ dari t tabel yaitu 2,811 > 2,67373 yang berarti jumlah bibit berpengaruh nyata terhadap produksi bawang merah di Kecamatan Tawangmangu pada tingkat kepercayaan $99 \%$. Jumlah bibit memiliki nilai elastisitas sebesar 0,443 yang artinya apabila ada penambahan jumlah bibit sebesar $1 \%$ maka terjadi peningkatan jumlah produksi bawang merah sebesar 0,443 \% dengan asumsi bahwa variabel lainnya dianggap nol atau konstan. Hasil tersebut sejalan dengan penelitian Rijal et al (2016) yang menyatakan bahwa jumlah bibit sebagai salah satu faktor yang mempengaruhi produksi bawang merah. Semakin banyak jumlah bibit yang ditanam, maka kemungkinan tanaman yang tumbuh juga banyak, sehingga produksi bawang merah yang dihasilkan juga banyak.

Pupuk kandang memiliki nilai $t$ hitung $<\mathrm{t}$ tabel yaitu $-0,274<2,00665$ yang berarti pupuk kandang tidak berpengaruh nyata terhadap produksi bawang merah di Kecamatan Tawangmangu. Hasil tersebut sejalan dengan penelitian Ismail et al (2019) yang menyatakan bahwa pupuk kandang tidak mempengaruhi produksi bawang merah. Penggunaan pupuk yang tidak sesuai dosis tersebut maka produktivitas per satuan lahan dapat menjadi berkurang, sehingga produksi mengalami penurunan. Pupuk kandang digunakan sebagai pupuk dasar, sehingga keberadaannya sangat penting untuk mengurai makanan dalam tanah yang akan diserap oleh tanaman.

Pupuk nitrogen memiliki nilai $t$ hitung $<t$ tabel yaitu $0,350<2,00665$ yang berarti pupuk nitrogen tidak berpengaruh nyata terhadap produksi bawang merah di Kecamatan Tawangmangu. Hasil tersebut sejalan dengan penelitian Fauzan et al (2019) yang menyatakan bahwa pupuk urea (pupuk nitrogen) tidak mempengaruhi produksi bawang merah. Rata-rata penggunaan pupuk nitrogen untuk satu kali musim tanam bawang merah di Kecamatan Tawangmangu sebanyak 10,9 kg untuk rata-rata luas lahan 0,053 ha. Apabila dikonversi dalam 1 hektar maka pupuk nitrogen yang digunakan sebanyak $205,7 \mathrm{~kg}$.

Pupuk fosfor memiliki nilai $\mathrm{t}$ hitung $<\mathrm{t}$ tabel yaitu 1,001 $<2,00665$ yang berarti pupuk fosfor tidak berpengaruh nyata terhadap produksi bawang merah di Kecamatan Tawangmangu. Hasil tersebut sejalan dengan penelitian Nurjati et al (2019) yang menyatakan bahwa pupuk anorganik tidak mempengaruhi produksi bawang merah. Rata-rata penggunaan pupuk fosfor untuk satu kali musim tanam bawang merah di Kecamatan

84

Afrianika et.al (Analisis Faktor-Faktor yang Mempengaruhi Produksi Usahatani Bawang Merah di Kecamatan Tawangmangu,Shallot, Production, Cobb-Douglas, Regression Analysis) 
Tawangmangu sebanyak 14,2 kg untuk rata-rata luas lahan 0,053 ha. Apabila dikonversi dalam 1 hektar maka pupuk fosfor yang digunakan sebanyak $267,3 \mathrm{~kg}$.

Pupuk kalium memiliki nilai $t$ hitung $<\mathrm{t}$ tabel yaitu $-0,943<2,00665$ yang berarti pupuk kalium tidak berpengaruh nyata terhadap produksi bawang merah di Kecamatan Tawangmangu. Hasil tersebut sejalan dengan penelitian Minarsih dan Lestari (2019) yang menyatakan bahwa pupuk KCL (pupuk kalium) tidak mempengaruhi produksi bawang merah. Rata-rata penggunaan pupuk kalium untuk satu kali musim tanam bawang merah di Kecamatan Tawangmangu sebanyak 5,5 kg untuk rata-rata luas lahan 0,053 ha. Apabila dikonversi dalam 1 hektar maka pupuk kalium yang digunakan sebanyak 104,3 kg.

Pestisida memiliki nilai t hitung $>\mathrm{t}$ tabel yaitu 2,296 > 2,00665 yang berarti pestisida berpengaruh nyata terhadap produksi bawang merah di Kecamatan Tawangmangu pada tingkat kepercayaan $95 \%$. Hasil tersebut sejalan dengan penelitian Widyantara dan Nengah (2013) yang menyatakan bahwa pestisida sebagai salah satu faktor yang mempengaruhi produksi bawang merah. Pestisida memiliki nilai elastisitas sebesar 0,194 yang artinya apabila ada penambahan pestisida sebesar $1 \%$ maka terjadi penambahan jumlah produksi bawang merah sebesar 0,194 \% dengan asumsi bahwa variabel lainnya dianggap nol atau konstan. Peranan pestisida terhadap produksi bawang merah berbeda dengan input lainnya. Pestisida tidak meningkatkan produksi tetapi menyelamatkan produksi dari serangan hama dan penyakit. Adapun hubungannya dengan peningkatan produksi terjadi karena tanaman yang sehat akan lebih responsif terhadap penyerapan unsur hara sehingga produksi bawang merah meningkat.

Nilai standar koefisien regresi parsial (koefisien beta) paling tinggi yaitu luas lahan dengan nilai sebesar 0,505 yang berarti luas lahan memiliki pengaruh paling besar dalam produksi bawang merah di Kecamatan Tawangmangu. Lahan merupakan faktor produksi yang sangat pokok dan menentukan dalam hal kegiatan usahatani. Luas lahan yang digarap tidak saja secara langsung berpengaruh terhadap produksi. Luas lahan juga akan mempengaruhi sistem pengelolaan usahatani, yang kemudian akan berpengaruh terhadap penggunaan teknologi, modal dan faktor produksi lain yang pada akhirnya akan berpengaruh terhadap produksi.

\section{KESIMPULAN}

Faktor luas lahan, jumlah bibit, dan pestisida berpengaruh signifikan terhadap produksi bawang merah di Kecamatan Tawangmangu. Sedangkan tenaga kerja, pupuk kandang, pupuk nitrogen, pupuk fosfor, dan pupuk kalium tidak berpengaruh signifikan terhadap produksi bawang merah di Kecamatan Tawangmangu. Faktor yang paling berpengaruh terhadap produksi bawang merah di Kecamatan Tawangmangu adalah luas lahan dengan nilai standar koefisien regresi parsial sebesar 0,505.

\section{DAFTAR PUSTAKA}

Awami S.N., Khalimatus S., dan Endah S. 2018. Faktor Yang Mempengaruhi Produksi Bawang Merah (Allium ascalonium L) di Kabupaten Demak. Jurnal AGRIFO Vol. 3 (2) : 35-44.

Fauzan, Bambang S. dan Farida S. 2019. Analisis Pengaruh Faktor-Faktor Produksi Bawang Merah di Desa Mranggon Lawang Kecamatan Dringu Kabupaten Probolinggo. Jurnal Sosial Ekonomi Pertanian dan Agribisnis Vol. 7 (4).

Gujarati, D. 2007. Ekonometrika Dasar. Jakarta : Erlangga.

Ismail, M., Masyhuri M. dan Farida S. 2019. Analisis Faktor-Faktor Yang Mempengaruhi Produksi Bawang Merah di Desa Torongrejo Kecamatan Junrejo Kota Batu. Jurnal Sosial Ekonomi Pertanian dan Agribisnis Vol. 7 (4).

Langi, H.L., Ignatius S.S. dan Ari A. 2019. Faktor-Faktor Sosial Ekonomi Yang Mempengaruhi Produksi Bawang Merah (Allium cepa L.) Lahan Sawah di Kelompok Tani Karangrejo Desa Gadingharjo Kecamatan Sanden Kabupaten Bantul. Jumal IImiah Agritas Vol. 3 (1) : 1-10.

Minarsih, I. dan Lestari R.W. 2019. Efisiensi Produksi pada Usahatani Bawang Merah di Kabupaten Madiun. Jurnal Ekonomi Pertanian dan Agribisnis Vol. 3 (1) : 128-137.

Mulyadi, D. 2017. Faktor yang Mempengaruhi Hasil Agribisnis Tanaman Pangan dan Hortikultura serta Implikasinya Terhadap Kesempatan Kerja dan Kesejahteraan Rumah Tangga Petani di Provinsi Jawa Barat. Jurnal Ekonomi Vol. 19 (2) : 18-48. 
Nurjati, E., Idqan F., dan Siti J. 2018. Analisis Efisiensi Produksi Bawang Merah di Kabupaten Pati dengan Fungsi Produksi Frontier Stokastik Cobb-Douglas. Jurnal Agro Ekonomi Vol. 36 (1) : 55-69.

Rijal, M., Fajri J. dan Widyawati. 2016. Analisis Faktor-Faktor Yang Mempengaruhi Produksi Usahatani Bawang Merah di Desa Lam Manyang Kecamatan Peukan Bada. Jurnal IImiah Mahasiswa Pertanian Unsyiah Vol. 1 (1) : 488-498.

Sadono, D. 2008. Pemberdayaan Petani : Paradigma Baru Penyuluhan Pertanian di Indonesia. Jurnal Penyuluhan Vol. 4 (1) : 65-74.

Sjamsir, Z. 2017. Pembangunan Pertanian dalam Pusaran Kearifan Lokal. Makassar : CV SAH MEDIA.

Soekartawi. 2003. Teori Ekonomi Produksi dengan Pokok Bahasan Analisis Cobb-Douglas. Jakarta : PT Raja Grafindo Persada.

Suliyanto. 2011. Ekonometrika Terapan - Teori dan Aplikasi dengan SPSS. Yogyakarta : CV. ANDI OFFSET.

Susanti, H., K. Budiraharjo dan M. Handayani. 2018. Analisis Faktor-Faktor Produksi Terhadap Produksi Usahatani Bawang Merah di Kecamatan Wanasari Kabupaten Brebes. Jurnal Sosial Ekonomi Pertanian Vol. 2 (1) : 23-30.

Widyantara, W. dan Nengah S.Y. 2013. Bias Manajemen Penggunaan Masukan dalam Usahatani Bawang Merah (Allium ascalonicum L). Jurnal Agrobisnis dan Agrowisata Vol. 2 (1) : 38-45. 